\title{
MODEL REGRESI LINIER SEDERHANA PENGARUH RASIO KEUANGAN TERHADAP PENDAPATAN PER PERIODE PT. TEMPO SCAN PASIFIC TBK.
}

\author{
Rukmono Budi Utomo ${ }^{1}$, Hairul Saleh ${ }^{2}$ \\ ${ }^{1,2}$ Pendidikan Matematika FKIP UMT
}

\begin{abstract}
Abstrak
Paper ini merupakan hasil penelitian yang membahas tentang hubungan dari pengaruh rasio keuangan terhadap pendapatan per periode pada PT Tempo Scan Pasific Tbk. Metodologi dalam penelitian ini menggunakan metode kajian pustaka, yakni dengan mempelajari laporan keuangan dari PT Tempo Scan Pasific, Tbk bagian rasio keuangan dan pendapatan per periode. Lebih lanjut, Peneliti mencoba mengolah data-data tersebut menggunakan SPSS untuk mencari model regresi linearnya. Dengan menggunakan metode Stepwise diperoleh bahwa Current Ratio merupakan Rasio keuangan yang berpengaruh pada pendapatan per periode PT Tempo Scan Pasific, Tbk dibandingkan jenis -jenis rasio keuangan lainnya seperti ROA, ROE, GPM, OPM dan NPM. Model Regresi yang terbentuk dapat dituliskan sebagai Profit $=2368.632-5.635 C R$.

Kata kunci: Model Regresi; Rasio Keuangan; Pendapatan Per Periode; PT Tempo Scan Pasific, Tbk.

Abstract

This Paper explains the result of research about relation between finance ratio and Profit per period at PT Tempo Scan Pasific, Tbk. Methodology of this research was literature study based on data from PT Tempo Scan Pasific, Tbk finance report. Data from that report processing using SPSS with the aim to get a linear regression model. Using Stepwise method, factually, Current Ratio is independent variable that support profit per period of PT Tempo Scan Pasific, Tbk. As an information, Finance ratios other were used of this paper as follows; ROA, ROE, GPM, OPM and NPM. Model regresi in this research results Profit $=2368.632-5.635 C R$.
\end{abstract}

Keywords: Regression Model; Finance Ratio; Profit PerPeriod; PT Tempo Scan Pasific, Tbk. 


\section{PENDAHULUAN}

PT Tempo Scan Pasific, Tbk merupakan perusahaan barang konsumen yang berdomisili di Jakarta. Perusahaan ini didirikan di Jakarta pada tanggal 3 November 1953 dan terdaftar sebagai perusahaan publik. PT Tempo Scan Pasific, Tbk mencatatkan dirinya pada lantai Bursa Efek Indonesia (BEI) pada tanggal 17 Juni 1994 atau sekitar 40 tahun kemudian semenjak perusahaan ini berdiri.

PT Tempo Scan Pasific, Tbk memproduksi berbagai jenis barang konsumen seperti obat-obatan dan vitamin. Contoh obat-obatan yang terkenal produksi perusahaan ini antara lain: Bodrex, Bodrexin, Oskadon, Oskadryl, dll, sedangkan untuk jenis vitamin yang terkenal antara lain Vitamin IPI dan Hemaviton.

Berdasarkan Laporan Keuangan Perusahan, PT Tempo Scan Pasific, Tbk pada tahun 2009 mencatatkan keuntungan sebesar 361 miliar rupiah. Selanjutnya pada tahun 2010, Perusahaan ini berhasil meningkatkan pendapatannya menjadi 495 miliar rupiah. Lonjakan peningkatan pendapatan ini cukup fantastis, karena perusahaan ini mampu menambah pendapatan lebih dari 100 miliar rupiah dalam 1 tahun. Pada tahun 2011, PT Tempo Scan Pasific, Tbk lagi-lagi dapat menambah pendapatannya yakni dengan pendapatan sebesar 586 miliar rupiah atau lebih dari setengah triliun rupiah.

Pada tahun berikutnya pendapatan perusahaan ini tetap meningkat dengan pendapatan sebesar 635 miliar rupiah meskipun di tahun berikutnya sempat mengalami penurunan pendapatan menjadi 579 miliar rupiah. Meski demikian, penurunan pendapatan perusahaan ini ditahun 2013 malih lebih besar dari pendapatan perusahaan pada tahun 2009 dan 2010. Pendapatan perusahaan pada tahun 2013 hanya selisih sedikit dibandingkan pendapatan pada tahun 2011. Pendapatan per periode PT Tempo Scan Pasific, Tbk dari tahun 2009 sampai 2013 dapat digambarkan pada gambar 1 di bawah ini.

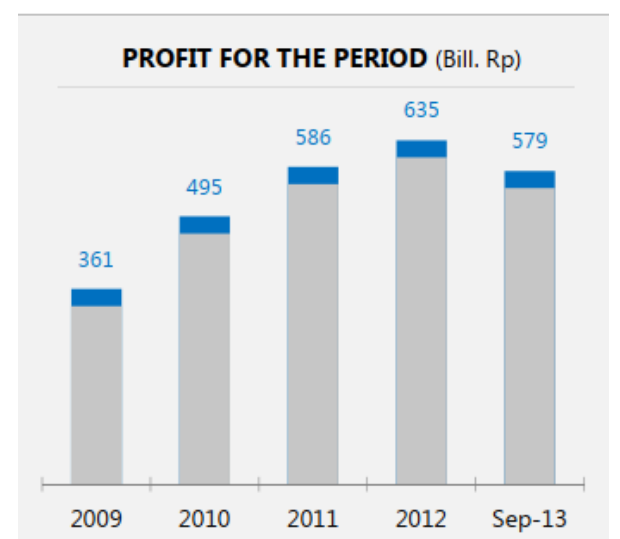

Gambar 1. Pendapatan PT Tempo Scan Pasific, Tbk dari periode 2009-2013 (IEFR)

Berdasarkan uraian di atas dan dari gambar 1 dapat disimpulkan bahwa PT Tempo Scan Pasific, Tbk dari tahun ke tahun mampu meraup keuntungan yang lebih besar. Meski sempat mengalami penurunan peningkatan pada tahun 2013, tetapi kondisi tersebut masih normal. Lebih lanjut sebenarnya apakah yang menjadi faktor kunci perusahaan ini mampu meningkatkan pendapatan perusahaan dari tahun ke tahun? Tentu faktornya banyak, namun berdasarkan hasil beberapa penelitian dari Rukmono (2017) Rasio Keuangan mempengaruhi persentase laba perusahaan manufaktur. Rukmono (2019) juga 
telah melakukan penelitian seputar model regresi yang mempengaruhi pendapatan bersih pada bank BCA.

Hapsari (2007) Juga telah melakukan penelitian tentang analisis perusahaan manufaktur terhadap pertumbuhan laba pada perusahaan manufaktur yang tercatat di BEI. Penelitian tentang hal ini juga dilakukan oleh Hapsari, yakni penelitian oleh Takarini, Nurjanti, Ekawari dan Erni (2003), bedanya Hapsari hanya meneliti untuk periode 2001 sampai 2005. Lebih lanjut ada penelitian dari Juliana, Roma Uly, dan Sulardi (2003) yang membahas rasio keuangan dalam memprediksi perubahan laba perusahaan manufaktur.

Berdasarkan penelitian yang sudah dijelaskan di atas, dapat disimpulkan bahwa rasio keuangan dapat mempengaruhi laba atau keuntungan per periode suatu perusahaan, misalnya perusahaan manufaktur. Lebih lanjut apakah rasio keuangan juga berpengaruh pada profit per periode PT Scan Tempo Pasific, Tbk? Kalaupun ya, bagaimana modelnya? Pertanyaan pertanyaan inilah yang dibahas di dalam paper ini. Pertanyaanpertanyaan tersebut pula yang menjadi motivasi penulis dalam melakukan penelitian ini yakni untuk menyelidiki hubungan dari rasio keuangan terhadap pendapatn per periode PT Tempo Scan Pasific, Tbk.

\section{METODE}

Metode penelitian yang dilakukan adalah dengan melakukan kajian pustaka laporan keuangan PT Tempo Scan Pasific, Tbk. Peneliti mencermati data rasio keuangan seperti Current Ratio (CR), ROA, ROE, GPM, NPM dan OPM. Tidak hanya data rasio keuangan yang dicermati, peneliti mencermati data profit perusahaan dari tahun 2009 sampai tahun 2013. Lebih lanjut, data-data tersebut dilakukan analisis regresi dengan bantuan perangkat lunak SPSS untuk mendapatkan model regresi. Metode yang dilakukan dengan menggunakan metode Stepwise. Setelah model regresi diperoleh, selanjutnya dilakukan analisis statistika dan ekonometrik seperti kenormalan, kelinieran, kehomogenan dan lain lain.

\section{HASIL DAN PEMBAHASAN}

Diberikan data rasio keuangan PT Tempo Scan Pasific, Tbk dan keuntungan atau profit pada periode 2009 sampai 2013 sebagai berikut

Tabel 1. Data Keuntungan PT. Tempo Scan Pasific, Tbk.

\begin{tabular}{|r|r|r|r|r|r|r|r|r||}
\hline & PROFIT & \multicolumn{1}{|c|}{ CR } & \multicolumn{1}{|c|}{ ROA } & \multicolumn{1}{|c|}{ ROE } & \multicolumn{1}{|c|}{ GPM } & \multicolumn{1}{|c|}{ OPM } & \multicolumn{1}{|c|}{ NPM } \\
\hline 1 & 361.00 & 346.84 & 11.06 & 14.98 & 37.25 & 9.91 & 8.02 \\
\hline \hline 2 & 495.00 & 336.85 & 13.78 & 19.00 & 36.90 & 11.51 & 9.64 \\
\hline \hline 3 & 586.00 & 308.30 & 13.80 & 19.25 & 38.06 & 11.47 & 10.14 \\
\hline \hline 4 & 635.00 & 309.33 & 13.71 & 18.94 & 37.53 & 11.19 & 9.58 \\
\hline \hline 5 & 579.00 & 329.05 & 11.14 & 15.20 & 39.91 & 12.92 & 11.52 \\
\hline \hline
\end{tabular}

Tabel 1 diatas memberikan arti bahwa nomor 1 sampai dengan 5 adalah tahun 2009 sampai tahun 2013. Profit pada tahun 2009 adalah sebesar 361 miliar rupiah, profit pada tahun 2010 adalah 495 miliar rupiah, profit pada tahun 2011 adalah 586 miliar rupiah, profit pada tahun 2012 adalah 635 miliar rupiah dan terakhir pada tahun 2013, perusahaan ini mendapatkan keuntungan 579 miliar rupiah. 
Rasio keuangan seperti Current Ratio (CR), ROA, ROE, GPM, OPM merupakan data dalam persentase.

Berdasarkan data tersebut, dilakukan penginputan data pada Tabel 1 ke dalam SPSS untuk selanjutnya dilakukan analisis regresi linier dengan menggunakan metode Stepwise. Sebenarnya ada berbagai metode dalam SPSS selain Stepwise, sebut saja metode Enter, metode Backward dan metode Forward, namun penulis lebih memilih metode stepwise dikarenakan metode ini biasanya dapat langsung memberikan model regresi linier yang memenuhi uji statistika. Uji statistika disini dapat berupa uji F, uji t, uji normalitas, uji linieritas, dan uji homogenitas. Selain itu ada pula uji non multikolinieritas, uji non autokorelasi, dan uji asumsi heteroskedastisitas. Lebih lanjut, hasil perhitungan dengan SPSS menghasilkan model regresi linier sederhana dengan koefisien model dijelaskan pada tabel 2 di bawah ini

Tabel 2. Koefisien Model Regresi

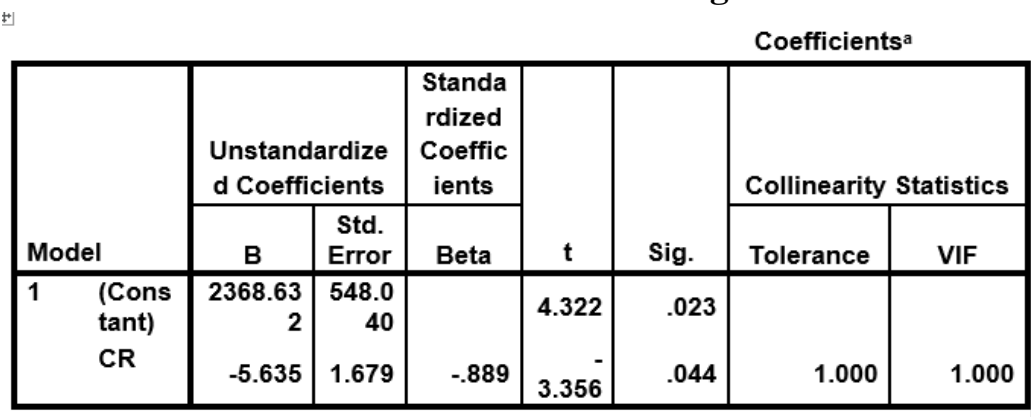

Pada tabel 2 di atas dapat dilihat bahwa nilai konstanta model regresi bernilai 2368,632 dan nilai koefisien dari CR adalah -5, 6535. Nilai signifikansi konstant adalah 0,023 dan nilai signifikansi $C R$ adalah $-3,356$ yang artinya adalah nilai signifikan keduanya kurang dari kesalahan alfa 5 persen atau dengan mengambil tingkat kepercayaan 95 persen. Nilai VIF CR adalah 1 yang kurang dari 5. Hal ini memberi arti bahwa CR terbebas dari multikolinieritas. Selanjutnya dari SPSS juga dihasilkan data Anova untuk menguji kecocokan model. Data Anova disajikan dalam tabel 3 sebagai berikut

Tabel 3. Anova

\begin{tabular}{|ll|r|r|r|r|r|}
\hline \multicolumn{1}{|c|}{ ANOVAa } \\
\hline 1 & Sum of Squares & \multicolumn{1}{c|}{$\mathrm{df}$} & Mean Square & \multicolumn{1}{c|}{$\mathrm{F}$} & Sig. \\
\hline & Regression & 36595.219 & 1 & 36595.219 & 11.265 & $.044^{\mathrm{b}}$ \\
& Residual & 9745.581 & 3 & 3248.527 & & \\
& Total & 46340.800 & 4 & & & \\
\hline
\end{tabular}

a. Dependent Variable: PROFIT

b. Predictors: (Constant), CR 
Untuk melihat seberapa besar kecocokan model yang dihasilkan, maka pada tabel 4 ini disajikan data nilai $R$ square. Nilai $R$ Square menunjukkan seberapa besar keakuratan suatu model regresi. Nilai $R$ Square yang mendekati nilai 1, maka model regresi semakin akurat, sebaliknya nilai $R$ square yang mendekati nol menunjukkan model semakin jauh dari aslinya. Dalam tabel 3 terdapat pula nilai Durbin-Watson (DW) yang memberikan informasi seputar apakah suatu data mengalami autokorelasi atau tidak. Model yang baik hendaknya yang terbebas dari autokorelasi atau uji non autokorelasi terpenuhi.

Tabel 4. Nilai R Square dan Durbin -Watson

\begin{tabular}{|c|c|c|c|c|c|c|c|c|c|c|}
\hline \multirow[b]{3}{*}{ Model } & \multirow[b]{3}{*}{$\mathrm{R}$} & \multirow[b]{3}{*}{$\begin{array}{c}\mathrm{R} \\
\text { Square }\end{array}$} & \multirow[b]{3}{*}{$\begin{array}{l}\text { Adjusted R } \\
\text { Square }\end{array}$} & \multicolumn{6}{|c|}{ Model Summary } & \multirow[b]{3}{*}{$\begin{array}{l}\text { Durbin- } \\
\text { Watson }\end{array}$} \\
\hline & & & & & \multicolumn{5}{|c|}{ Change Statistics } & \\
\hline & & & & $\begin{array}{l}\text { Std. Error of the } \\
\text { Estimate }\end{array}$ & R Square Change & F Change & df1 & $\mathrm{df} 2$ & $\begin{array}{c}\text { Sig. F } \\
\text { Change }\end{array}$ & \\
\hline 1 & $.889^{\mathrm{a}}$ & .790 & .720 & 56.99585 & .790 & 11.265 & 1 & 3 & .044 & 1.741 \\
\hline
\end{tabular}

Setelah diperoleh data hasil perhitungan dari SPSS, selanjutnya dibahas maksud hasil tabel 1, tabel 2 dan tabel 3 dan tabel 4 di atas. Pembahasan dimulai dari tabel 2, hasil tersebut menunjukkan bahwa model regresi yang terbentuk untuk menjelaskan hubungan antara rasio keuangan terhadap keuntungan per periode PT Tempo Scan Pasific, Tbk adalah model regresi linier sederhana yang dinyatakan sebagai

$$
\text { Profit }=2368.632-5.635 C R
$$

Pada model (1) di atas disampaikan bahwa profit atau keuntungan per periode perusahaan dipengaruhi oleh variabel CR. Lebih lanjut dari pada itu, uji kecocokan model dapat dilihat dari nilai signifikansi (sig) pada tabel 3 Anova. Apabila nilai sig $<0.05$, maka model cocok diterapkan. Pada tabel 3 terlihat nilai sig $=0.044<0.05$, dengan demikian maka model (1) cocok diterapkan.

Setelah dilakukan uji F, selanjutnya dilakukan uji-t. Karena model regresi yang terbentuk hanya terdiri dari CR, maka uji-t yang dilakukan hanya diperuntukkan bagi variabel tersebut. Uji-t dilakukan dengan melihat nilai signifikansi $\mathrm{CR}<\alpha=0$, 05. Apabila hal tersebut terpenuhi, maka uji-t lulus. Dengan kata lain CR berpengaruh terhadap model regresi yang terbentuk. Pada tabel 3, terlihat nilai signifikansi sebesar $0,044<\alpha=0$, 05, yang artinya rasio keuangan CR memiliki pengaruh terhadap model regresi yang terbentuk.

Setelah dilakukan uji $\mathrm{F}$ dan uji-t maka selanjutnya dilakukan uji ekonometrik yakni melihat kenormalan, kelinieritasan, dan kehomogenitasan data. Pada gambar 1,2, dan 3 di bawah ini terlihat bahwa data yang digunakan dalam penelitian ini bersifat normal. Berdasarkan hal tersebut uji normalitas terpenuhi. Arti Normalitas disini adalah data yang dikumpulkan bersifat normal atau ideal, tidak tinggi sebelah atau rendah sebelah atau dengan kata lain tidak timpang. Selanjutnya pada gambar 2, terlihat bahwa data terletak di sekitar garis linier. 
Berdasarkan hal tersebut uji linieritas terpenuhi. Linier disini berarti model yang terbentuk memang pantas didekati secara linier dan bukan berbentuk polynomial, eksponensial, logaritma atau yang lainnya. Selanjutnya pada gambar 3 terlihat data tersebar secara acak. Hal ini memberi arti bahwa uji homogenitas terpenuhi. Homogen disini memberi arti bahwa data yang dikumpulkan adalah data yang acak dan tidak membentuk suatu pola-pola tertentu, misalnya pola cekung, cembung, parabola tertentu, atau yang lain. Dalam kata lain data-data yang terkumpul adalah heterogen atau acak dan bukan homogen, hal inilah yang dimaksud dari uji homogenitas dalam statistika. Lebih lanjut gambar plot SPSS yang menunjukkan kelulusan uji Normalitas, Uji linieritas dan Uji Homogenitas dapat diperhatikan pada gambar 1, gambar 2 dan gambar 3 berturut-turut di bawah ini.
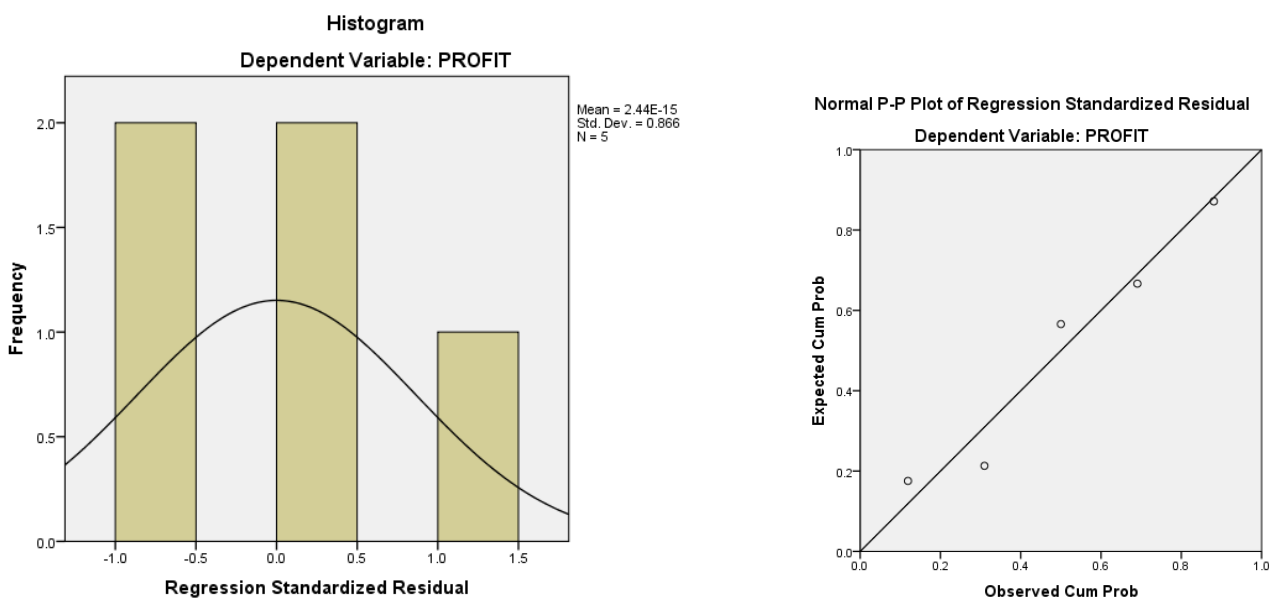

Gambar 1. Kenormalan Data Gambar 2. Kelinieran data

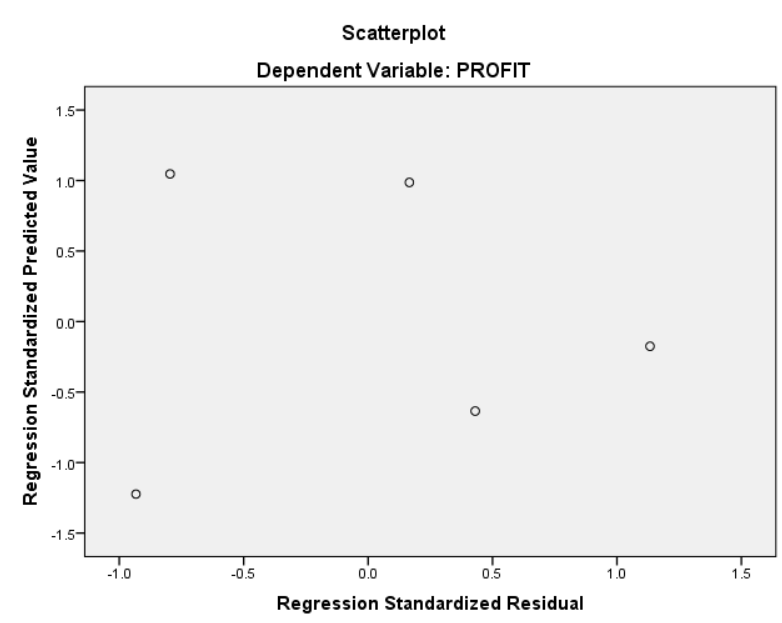

Gambar 3. Kehomogenan Data

Setelah dilakukan uji normalitas, uji linieritas, dan uji homogenitas, selanjutnya dilakukan uji non multikolinieritas, uji non autokorelasi, dan uji 
asumsi heteroskedastisitas. Uji non multikolinieritas dilakukan dengan melihat nilai VIF. Jika nilai VIF pada CR kurang dari 5 maka model regresi yang terbentuk terbebas dari multikolinieritas. Pada tabel 2 terlihat nilai VIF CR sama dengan 1. Berdasarkan hal tersebut uji non multikolinearitas terpenuhi. Sebenarnya ada beberapa versi terkait uji non multikolinieritas. Pada beberapa literatur kadang disebutkan bahwa uji non multikolinieritas dapat dilihat dari nilai VIF Variabel bebas yang kurang dari 10. Berdasarkan pendapat ini, berarti meski nilai VIF suatu variabel yang lebih dari 5 tetap memenuhi uji non multikolinieritas asalkan kurang dari 10. Terlepas dari hal demikian, lebih meyakinkan apabila menggunakan pendapat yang mengatakan bahwa uji non multikolinearitas terpenuhi apabila nilai VIF suatu variabel pada model regresi yang terbentuk kurang dari 5. Hal ini didasari bahwa nilai VIF yang kurang dari 5 lebih akurat dalam pengujian dan aman serta bebas dari keragu-raguan.

Selanjutnya uji non autokorelasi dilihat dari kriteria Durbin-Watson (DW). Pada tabel 4, terlihat bahwa nilai DW samadengan 1.741 dan berada di antara 1 dan 5 . Berdasarkan hal tersebut, uji non autokorelasi terpenuhi. Nilai $R$ Square menunjukkan 0.79, artinya model (1) memiliki keakuratan sebesar 79 persen dan selebihnya disebabkan pengaruh variabel. Karena model regresi dalam paper ini merupakan model regresi biasa, maka pada umumnya uji asumsi heteroskedastisitas otomatis terpenuhi. Dengan dilakukannya uji statistika dan ekonometerik maka hasil dari penelitian telah lengkap.

\section{KESIMPULAN}

Kesimpulan dari penelitian ini dapat diuraikan sebagai berikut:

1. Model regresi yang menjelaskan pengaruh rasio keuangan terhadap pendapatan per periode PT Tempo Scan Pasific Tbk dapat dijelaskan sebagai

Profit $=2368.632-5.635 C R$. Model ini merupakan model regresi linier sederhana dengan variabel bebas $\mathrm{CR}$.

2. Model di atas memiliki keakuratan sebesar $79 \%$, selebihnya sekitar $21 \%$ model ini dipengaruhi oleh faktor lain. Keakuratan model dapat ditinjau kembali pada tabel 3 .

3. Model regresi telah melalui berbagai uji statistika dan ekonometrik.

Untuk penelitian lebih lanjut (Saran) sebaiknya dapat menggunakan faktor-faktor lain yang diperkirakan dapat mempengaruhi pendapatan bersih PT Tempo Scan Pasific Tbk Tbk.

\section{DAFTAR RUJUKAN}

[1] Anonim. 2019. PT Tempo Scan Pasific, Tbk. Https://Wikipedia.org. Diakses 24 November 2020 Sekitar Pukul 15.00 WIB

[2] IEFR. (2013). Laporan Perusahaan PT Tempo Scan Pasific, Tbk, Tbk. ICMD.

[3] Utomo, Rukmono Budi. (2 017). Model Regresi Persentase Keuntungan Perusahaan Manufaktur Ditinjau Dari Faktor Rasio Keuangan Berdasarkan Data ICMD. Jurnal Silogisme Vol. 2 No. 1. 
[4] Utomo, Rukmono Budi. (2017). Model Matematika Pengaruh Rasio Keuangan Terhadap Persentase Laba Perusahaan Manufaktur Dengan Menggunakan Metode Dekomposisi Lower- Upper Gauss. Jurnal Gammath Vol. 2 No. 1

[5] Utomo, Rukmono Budi. (2019). Model Regresi Pengaruh Rasio Keuangan Terhadap Pendapatan Bersih PT Bank Central Asia (BCA) Tbk. Jurnal Silogisme Volume 4 no 1 tahun 2019

[6] Hapsari, Epri Ayu. 2007. "Analisis Rasio Keuangan Untuk Memprediksi Pertumbuhan Laba (Studi Kasus Perusahaan Manufaktur Yang Terdaftar di Bursa Efek Jakarta Tahun 2001 Sampai Tahun 2005). "Universitas Diponegoro

[7] Takarini, Nurjanti, Ekawarni, dan Erni. 2003. "Analisis Rasio Keuangan Dalam Memprediksi Perubahan Laba Perusahaan Manufaktur di Pasar Modal Indonesia." Ventura 6 (3)

[8] Juliana, Roma Uly, dan Sulardi. 2003 "Manfaat Rasio Keuangan dalam Memprediksi Perubahan Laba Perusahaan Manufaktur." Jurnal Bisnis dan Managemen 3(2) 